\title{
Racemization-free synthesis of $\mathrm{Na}$-2-thiophenoyl-phenylalanine-2- morpholinoanilide enantiomers and their antimycobacterial activity
}

\author{
Lea Mann ${ }^{1} \cdot$ Markus Lang ${ }^{1} \cdot$ Philipp Schulze ${ }^{2} \cdot$ Jan Henrik Halz ${ }^{3} \cdot$ René Csuk $^{3}$ (D) Sophie Hoenke ${ }^{3}$. \\ Rüdiger W. Seidel ${ }^{1}$ (1) Adrian Richter ${ }^{1}$ (1)
}

Received: 10 December 2020 / Accepted: 7 June 2021 / Published online: 14 July 2021

(c) The Author(s) 2021

\begin{abstract}
$N \alpha$-2-thiophenoyl-D-phenylalanine-2-morpholinoanilide (MMV688845, IUPAC: $N$-(1-((2-morpholinophenyl)amino)-1-oxo3-phenylpropan-2-yl)thiophene-2-carboxamide) from the Pathogen Box ${ }^{\circledR}$ library (Medicines for Malaria Ventures, MMV) is a promising lead compound for antimycobacterial drug development. Two straightforward synthetic routes to the title compound starting from phenylalanine or its Boc-protected derivative are reported. Employing Boc-phenylalanine as starting material and the $\mathrm{T} \mathrm{P}^{\circledR}$ and $\mathrm{PyBOP}{ }^{\circledR}$ amide coupling reagents enables racemization-free synthesis, avoiding the need for subsequent separation of the enantiomers. The crystal structure of the racemic counterpart gives insight into the molecular structure and hydrogen bonding interactions in the solid state. The $R$-enantiomer of the title compound (derived from D-phenylalanine) exhibits activity against non-pathogenic and pathogenic mycobacterial strains, whereas the $S$-enantiomer is inactive. Neither of the enantiomers and the racemate of the title compound shows cytotoxicity against various mammalian cells.
\end{abstract}

Keywords Amino acid · Phenylalanine amides · MMV688845 - GSK1055950A · Racemization-free synthesis · Enantioselective activity $\cdot$ Antimycobacterial activity $\cdot$ Crystal structure

\section{Introduction}

Mycobacterial infections are a challenge for anti-infective drug therapy due to a high level of intrinsic and acquired resistance of the pathogens, which usually makes long-time treatments with combined antibiotics necessary (Zumla et al. 2014; To et al. 2020). Rifampicin, an inhibitor of the mycobacterial RNA polymerase with bactericidal activity (Grobbelaar et al. 2019), is a cornerstone for treatment of Mycobacterium tuberculosis infections. It belongs to the rifamycin

Handling Editor: P. Meffre.

Adrian Richter

adrian.richter@pharmazie.uni-halle.de

1 Institut für Pharmazie, Martin-Luther-Universität Halle-Wittenberg, Wolfgang-Langenbeck-Str. 4, 06120 Halle (Saale), Germany

2 Max-Planck-Institut für Kohlenforschung, Kaiser-Wilhelm-Platz 1, 45470 Mülheim an der Ruhr, Germany

3 Institut für Chemie, Martin-Luther-Universität Halle-Wittenberg, Kurt-Mothes Str. 2, 06120 Halle (Saale), Germany group, the only class of antibiotics with sterilizing activity in caseum (necrotic tissue in granulomas) (Prideaux et al. 2015; Ganapathy et al. 2019). Infections with rifampicinresistant mycobacteria, e.g. multidrug-resistant $M$. tuberculosis (MDR-Tb) (Stoffels et al. 2013; Dartois et al. 2019; Shah et al. 2020) or Mycobacterium abscessus (Nessar et al. 2012; Lopeman et al. 2019), are an arising issue for antimycobacterial chemotherapy. M. abscessus infections are particularly difficult to treat, because of a high level of intrinsic resistance against many antitubercular drugs (Nessar et al. 2012; Lee et al. 2015; Bryant et al. 2016). In most cases, patients with a suppressed immune status or a structural lung disease, e.g. cystic fibrosis (Park and Olivier 2015), are affected. Non-tubercular mycobacteria not only cause lung tissue infections (Weiss and Glassroth 2012; Wassilew et al. 2016), but also affect the skin, soft tissue and the central nervous system (Ahmed et al. 2020). Development of new antibiotics is needed to overcome drug resistance and to provide new options for treatment (Wu et al. 2018).

$N \alpha$-2-thiophenoyl-phenylalanine-2-morpholinoanilide (IUPAC: $N$-(1-((2-morpholinophenyl)amino)-1-oxo-3-phenylpropan-2-yl)thiophene-2-carboxamide), the title compound, is a promising lead candidate for anti-mycobacterial 
drug development (Ballell et al. 2013) with activity against highly drug-resistant non-tubercular mycobacteria, e.g. $M$. abscessus and Mycobacterium avium (Ebright et al. 2015; Low et al. 2017; Richter et al. 2018; Jeong et al. 2018). The $R$-enantiomer is contained in the Pathogen Box ${ }^{\circledR}$ library (Medicines for Malaria Venture, MMV, Geneva, Switzerland), as MMV688845. Crystal structures and enzyme inhibition assays with closely related compounds indicate that the activity of $N \alpha$-aroyl- $N$-aryl-phenylalanine amides is caused through inhibition of the RNA polymerase in $M$. tuberculosis (Lin et al. 2017). The clinical importance of RNA polymerase inhibitors mentioned above underlines the suitability of the target for drug development. Since $N \alpha$-aroyl- $N$-aryl-phenylalanine amides interact with a binding site different from that of rifamycins, they have a broader spectrum of activity and there is no cross resistance observed (Lin et al. 2017). MMV688845 was selected for further investigation because it is one of the few RNA polymerase inhibitors that shows significant activity against M. abscessus. Thus far, this class of compounds has hardly been studied against non-tuberculous mycobacteria, making it an interesting starting point for further investigation and structural optimisation.

Herein, we report on straightforward synthesis of $N \alpha-2-$ thiophenoyl-phenylalanine-2-morpholinoanilide from enantiopure phenylalanine or its Boc-protected derivatives in two steps via two different synthetic routes, one of which leads to racemization, whereas the other preserves a high degree of enantiomeric purity. Both enantiomers of the title compound were synthesized and studied by circular dichroism (CD) spectroscopy and chiral HPLC. The racemic counterpart was structurally characterized by X-ray crystallography. Activities of both enantiomers and the racemate against fast-growing mycobacteria, viz. M. abscessus and Mycobacterium smegmatis, and their cytotoxicity against mammalian cells were evaluated to gain insight into configurational effects of this compound class.

\section{Materials and methods}

\section{General}

Starting materials were purchased and used as received. Solvents were distilled prior to use and stored over $4 \AA$ molecular sieves. Glassware was oven-dried at $110{ }^{\circ} \mathrm{C}$. Column chromatography was carried out using Merck silica gel 60 (63-200 $\mu \mathrm{m})$. Flash chromatography was performed on a puriFlash $^{\circledR} 430$ instrument (Interchim, Montluçon, France). Prepacked columns with silica gel $(30 \mu \mathrm{m})$ were used. The maximum compound load per column was $5 \%(\mathrm{~m} / \mathrm{m})$ of the silica gel quantity. NMR spectra were recorded on an Agilent Technologies VNMRS $400 \mathrm{MHz}$ spectrometer.
Chemical shifts are reported relative to the residual solvent signal $\left(\mathrm{CDCl}_{3}: \delta_{\mathrm{H}}=7.26 \mathrm{ppm} ; \delta_{\mathrm{C}}=77.36 \mathrm{ppm} ; \mathrm{CD}_{3} \mathrm{OD}\right.$ $\delta_{\mathrm{H}}=3.31 \mathrm{ppm} ;$ DMSO- $\left.d 6 \delta_{\mathrm{H}}=2.50 \mathrm{ppm}\right)$. Abbreviations: $s$ singlet, $b s$ broad singlet, $d$ doublet, $d d$ doublet of doublets, $m$ multiplet. ESI mass spectra were measured on a Thermo Finnigan LCQ Classic spectrometer and high-resolution mass spectra (HRMS) were recorded on a Thermo Fisher Scientific LTQ Orbitrap XL mass spectrometer. Achiral HPLC analyses were performed using an Agilent 1260 HPLC instrument equipped with UV diode array detection (50 mm Eclipse Plus C18 $1.8 \mu \mathrm{m}, 4.6 \mathrm{~mm}$, methanol/ water gradient, $v=1.0 \mathrm{~mL} \mathrm{~min}{ }^{-1}, \lambda_{\text {used }}=220 \mathrm{~nm}$ ), and $e e$ determinations were conducted using a Shimadzu Prominence LC-20A HPLC instrument with diode array detection (150 mm Chiralpak IB-N3, $4.6 \mathrm{~mm}$, acetonitrile/ water 55:45, v=1.0 mL min ${ }^{-1}, \lambda_{\text {used }}=220 \mathrm{~nm}$ for compound 2; $150 \mathrm{~mm}$ Chiralpak IC-3, $4.6 \mathrm{~mm}$, acetonitrile/ water $+0.1 \%$ TFA $30: 70, v=1.0 \mathrm{~mL} \mathrm{~min}^{-1}, \lambda_{\text {used }}=220 \mathrm{~nm}$ for compound 1a).

UV spectra were acquired with a Jasco V-770 UV/Vis spectrophotometer, using $10 \mathrm{~mm}$ path length cuvettes, and specific rotation with a Jasco P-2000 polarimeter, using $100 \mathrm{~mm}$ path length cuvettes. Circular dichroism spectra were measured with a Jasco J-815 spectrometer, using $1 \mathrm{~mm}$ path length cuvettes. Differential Scanning Calorimetry (DSC) was carried out on a Mettler Toledo DSC 823e Module instrument using a standard aluminium sample pan.

\section{Synthesis}

\section{Method A}

Na-2-thiophenoyl-L-phenylalanine (1a) 2-Thiophenecarboxylic acid (403 $\mathrm{mg}, 3.15 \mathrm{mmol}$ ) and thionyl chloride $(1135 \mu \mathrm{L}, 15.6 \mathrm{mmol})$ were heated under reflux in toluene $(16 \mathrm{~mL})$ for $5 \mathrm{~h}$ under nitrogen. After cooling to room temperature, the excess of thionyl chloride and toluene was removed under reduced pressure, and the residue was dissolved in acetonitrile. The 2-thiophenecarbonyl chloride so formed was added to a stirred solution of L-phenylalanine $(500 \mathrm{mg}, 3.0 \mathrm{mmol})$ and potassium carbonate $(1656 \mathrm{mg}$, $12.0 \mathrm{mmol})$ in acetonitrile/water $(4: 1,10 \mathrm{~mL})$ at $0^{\circ} \mathrm{C}$. The mixture was stirred for $4 \mathrm{~h}$ at room temperature. Subsequently, the solvents were removed under reduced pressure and hydrochloric acid (36\%) was added to the residue, followed by extraction with diethyl ether $(3 \times 20 \mathrm{~mL})$. The combined organic layers were dried over sodium sulfate and the solvent was removed under reduced pressure. The crude product was purified by column chromatography eluting with ethyl acetate/heptane $(1: 1)+1 \%$ formic acid. Yield: $594 \mathrm{mg}$ (2.16 mmol, 72\%; HPLC purity $94.7 \%, t_{\mathrm{R}}=19.2 \mathrm{~min}, 99.1 \%$ ee) colourless, glass-like substance. ${ }^{1} \mathrm{H}$ NMR $(400 \mathrm{MHz}$, $\left.\mathrm{CD}_{3} \mathrm{OD}\right): \delta=7.66(\mathrm{dd}, \mathrm{Ar}-\mathbf{H}, J=3.7,1.3 \mathrm{~Hz}, 1 \mathrm{H}), 7.63-7.56$ 
(m, Ar-H, 1H), 7.29-7.21 (m, Ar-H, 4H), 7.21-7.15 (m, Ar-H, 1H), 7.11-7.04 (m, Ar-H, 1H), 4.86-4.79 (m, CH$\left.\mathrm{CH}_{2}, 1 \mathrm{H}\right), 3.33$ (dd, $\left.\mathrm{CH}-\mathrm{CH}_{2}, J=13.9,5.3 \mathrm{~Hz}, 1 \mathrm{H}\right), 3.11$ (dd, $\left.\mathrm{CH}-\mathrm{CH}_{2}, J=13.9,9.2 \mathrm{~Hz}, 1 \mathrm{H}\right) \mathrm{ppm}$. HRMS $\left(\mathrm{ESI}^{+}\right)$ $\mathrm{m} / \mathrm{z}[\mathrm{M}+\mathrm{H}]^{+}$calcd for $\mathrm{C}_{14} \mathrm{H}_{14} \mathrm{NO}_{3} \mathrm{~S}^{+}, 276.0690$ found, 276.0690. Specific rotation, $[\alpha]_{\mathrm{D}}^{25}-48.4$ (c 0.130, MeOH).

rac-Na-2-thiophenoyl-phenylalanine-2-morpholinoanil ide (rac-2) Compound 1a (100 mg, $0.55 \mathrm{mmol}), \mathrm{PyBOP}^{\circledR}$ (314 mg, $0.61 \mathrm{mmol}$ ) and diisopropylethylamine $(153 \mu \mathrm{L}$, $0.88 \mathrm{mmol})$ were dissolved in dichloromethane $(10 \mathrm{~mL})$. After addition of 2-morpholinoaniline $(100 \mathrm{mg}, 0.55 \mathrm{mmol})$, the reaction mixture was stirred overnight. Solvents were then removed under reduced pressure and the crude product was purified by column chromatography with ethyl acetate/heptane (1:1) followed by washing with heptane/ chloroform (95:5). Yield: $125 \mathrm{mg}$ (0.29 mmol, 52\%; HPLC purity $\left.98.8 \%, t_{\mathrm{R}}=4.3 \mathrm{~min}\right)$, white solid, m.p. $181-182{ }^{\circ} \mathrm{C}$. ${ }^{1} \mathrm{H}$ NMR (400 MHz, $\mathrm{CDCl}_{3}$ ): $\delta=8.87$ (s, NH, 1H), 8.38 (d, Ar-H, $J=8.1 \mathrm{~Hz}, 1 \mathrm{H}), 7.54$ (dd, Ar-H, $J=3.8,1.3 \mathrm{~Hz}$, $1 \mathrm{H}), 7.51$ (dd, Ar-H, J=5.0, $1.1 \mathrm{~Hz}, 1 \mathrm{H}), 7.33-7.26(\mathrm{~m}$, Ar-H, 4H), 7.24-7.05 (m, Ar-H, 5H), 6.78 (s, NH, 1H), 4.94 (m, CH-CH $\mathrm{CH}_{2}, 1 \mathrm{H}$ ), 3.63 (bs, $\mathrm{CH}_{2}-\mathrm{O}-\mathrm{CH}_{2}, 4 \mathrm{H}$ ), 3.38 (dd, $\left.\mathrm{CH}-\mathrm{CH}_{2}, J=13.6,5.4 \mathrm{~Hz}, 1 \mathrm{H}\right), 3.22$ (dd, $\mathrm{CH}-\mathrm{CH}_{2}, J=13.6$, $8.0 \mathrm{~Hz}, 1 \mathrm{H}), 2.64\left(\mathrm{~m}, \mathrm{CH}_{2}-\mathrm{N}-\mathrm{CH}_{2}, 4 \mathrm{H}\right) \mathrm{ppm} .{ }^{13} \mathrm{C} \mathrm{NMR}$ $\left(101 \mathrm{MHz}, \mathrm{CDCl}_{3}\right): \delta=168.9,161.7,141.1,138.1,136.6$, $133.0,130.9,129.5,129.0,128.8,128.0,127.3,126.1$, 124.6, 120.9, 120.0, 67.3, 56.3, 52.7, 38.7, HRMS (ESI $\left.{ }^{+}\right)$ $m / z[\mathrm{M}+\mathrm{H}]^{+}$calcd for $\mathrm{C}_{24} \mathrm{H}_{26} \mathrm{~N}_{3} \mathrm{O}_{3} \mathrm{~S}^{+}, 436.1690$; found, 436.1689; $[\mathrm{M}+\mathrm{Na}]^{+}$calcd for $\mathrm{C}_{24} \mathrm{H}_{25} \mathrm{~N}_{3} \mathrm{O}_{3} \mathrm{SNa}^{+}$, 458.1509; found: 458.1508 .

\section{Method B}

Boc-L-phenylalanine-2-morpholinoanilide ( $S$-1b) A solution of Boc-L-phenylalanine (372 $\mathrm{mg}, 1.4 \mathrm{mmol})$ and 2-morpholinoaniline $(231 \mathrm{mg}, 1.3 \mathrm{mmol})$ in ethyl acetate/ pyridine $\left(2: 1,10 \mathrm{~mL}\right.$ ) and cooled to $-20{ }^{\circ} \mathrm{C}$ (isopropanoldry ice bath), and a solution of $\mathrm{T} 3 \mathrm{P}^{\circledR}$ in ethyl acetate $(50 \%$, $1.67 \mathrm{~mL}, 2.8 \mathrm{mmol}$ ) was added in small portions. The reaction mixture was stirred overnight at $0{ }^{\circ} \mathrm{C}$ in an ice bath. Subsequently, ethyl acetate $(20 \mathrm{~mL})$ was added and the mixture was washed with $0.5 \mathrm{~N}$ hydrochloric acid $(1 \times 30 \mathrm{~mL})$. The organic layer was dried over sodium sulfate, and the solvent was removed under reduced pressure. The crude product was purified by flash chromatography eluting with ethyl acetate/heptane. Yield: $476 \mathrm{mg}$ (1.12 mmol, 80\%; HPLC purity $99.9 \%, t_{\mathrm{R}}=14.2 \mathrm{~min}$ ), white solid, m.p. $158-159{ }^{\circ} \mathrm{C}$. ${ }^{1} \mathrm{H}$ NMR (400 MHz, $\left.\mathrm{CDCl}_{3}\right): \delta 8.93(\mathrm{~s}, \mathrm{NH}, 1 \mathrm{H}), 8.41(\mathrm{~d}$, Ar-H, $J=8.1 \mathrm{~Hz}, 1 \mathrm{H}), 7.31-7.02$ (m, Ar-H, 8H), 5.09 (s, $\mathrm{NH}, 1 \mathrm{H}), 4.58-4.40$ (m, CH-CH, $1 \mathrm{H}), 3.76-3.58$ (m, $\mathrm{CH}_{2^{-}}$ O-CH $\mathbf{H}_{2}, 4 \mathrm{H}$ ), 3.18 (dd, CH-CH $, J=11.8,2.5 \mathrm{~Hz}, 1 \mathrm{H}$ ), 3.17 $\left(\mathrm{dd}, \mathrm{CH}-\mathrm{CH}_{2}, \mathrm{~J}=11.8,3.1 \mathrm{~Hz} 1 \mathrm{H}\right), 2.72-2.51\left(\mathrm{~m}, \mathrm{CH}_{2^{-}}\right.$
$\left.\mathrm{N}-\mathrm{CH}_{2}, 4 \mathrm{H}\right), 1.41$ (s, $\left.\mathrm{C}\left(\mathrm{CH}_{3}\right)_{3}, 9 \mathrm{H}\right)$ ppm. HRMS $\left(\mathrm{ESI}^{+}\right)$: $\mathrm{m} / \mathrm{z}[\mathrm{M}+\mathrm{H}]^{+}$calcd for $\mathrm{C}_{24} \mathrm{H}_{32} \mathrm{~N}_{3} \mathrm{O}_{4}{ }^{+}, 426.2388$; found: 426.2381. Specific rotation, $[\alpha]_{\mathrm{D}}^{25}-21.1$ ( $\left.c 0.107, \mathrm{MeOH}\right)$.

Na-2-thiophenoyl-L-phenylalanine-2-morpholinoanilide (S-2) Compound $S$-1b (100 mg, $0.24 \mathrm{mmol}$ ) was dissolved in dichloromethane/trifluoroacetic acid (1:1) and stirred for $1 \mathrm{~h}$ at room temperature. The solvent was removed under reduced pressure, and the crude product was co-evaporated successively thrice with toluene and thrice with chloroform. The residue was dissolved in dichloromethane followed by addition of diisopropylethylamine $(68 \mu \mathrm{L}, 0.72 \mathrm{mmol})$ and 2-thiophenecarboxylic acid (31 $\mathrm{mg}, 0.24 \mathrm{mmol})$. A solution of $\mathrm{PyBOP}^{\circledR}(135 \mathrm{mg}, 0.26 \mathrm{mmol})$ in dichloromethane was added under light protection and argon. After stirring in the dark overnight, the reaction mixture was washed twice with $0.5 \mathrm{~N}$ hydrochloric acid. The organic layer was dried over dried over sodium sulfate and the solvent was removed under reduced pressure. The crude product was purified by flash chromatography eluting with ethyl acetate/ heptane. Yield: $32 \mathrm{mg}(0.07 \mathrm{mmol}, 31 \%$; HPLC purity $\left.98.5 \% ; t_{\mathrm{R}}=4.3 \mathrm{~min}, 99.9 \% e e\right)$ colourless, glass-like substance. ${ }^{1} \mathrm{H}$ NMR $\left(400 \mathrm{MHz}, \mathrm{CDCl}_{3}\right): \delta=8.82(\mathrm{~s}, \mathrm{NH}, 1 \mathrm{H})$, 8.38 (d, Ar-H, J=8.1 Hz, 1H), 7.57-7.46 (m, Ar-H, 2H), 7.33-7.26 (m, Ar-H, 4H), 7.24-7.04 (m, Ar-H, 5H), 6.70 (d, NH, J=7.7 Hz, 1H), 4.94 (m, CH-CH $\left.\mathrm{CH}_{2} 1 \mathrm{H}\right), 3.61$ (bs, $\left.\mathrm{CH}_{2}-\mathrm{O}-\mathrm{CH}_{2}, 4 \mathrm{H}\right), 3.39$ (dd, $\mathrm{CH}-\mathrm{CH}_{2}, J=13.6,5.4 \mathrm{~Hz}$, 1H), 3.23 (dd, CH-CH $, J=13.6,8.1 \mathrm{~Hz}, 1 \mathrm{H}), 2.63(\mathrm{~m}$, $\left.\mathrm{CH}_{2}-\mathrm{N}-\mathrm{CH}_{2}, 4 \mathrm{H}\right)$, APT ${ }^{13} \mathrm{C} \mathrm{NMR}\left(101 \mathrm{MHz}, \mathrm{CDCl}_{3}\right)$ : $\delta=168.9,161.7,141.3,138.1,136.6,133.0,131.0,129.5$, 129.0, 128.8, 127.9, 127.3, 125.8, 124.5, 120.9, 119.7, 67.3, 56.3, 52.6, 38.6 ppm. HRMS $\left(\mathrm{ESI}^{+}\right): \mathrm{m} / \mathrm{z}[\mathrm{M}+\mathrm{H}]^{+}$calcd for $\mathrm{C}_{24} \mathrm{H}_{26} \mathrm{~N}_{3} \mathrm{O}_{3} \mathrm{~S}^{+}$, 436.1695; found: 436.1686; [M+Na $]^{+}$ calcd. for $\mathrm{C}_{24} \mathrm{H}_{25} \mathrm{~N}_{3} \mathrm{O}_{3} \mathrm{SNa}^{+}$, 458.1509; found: 458.1507 . Specific rotation, $[\alpha]_{\mathrm{D}}^{25}-51.5(c 0.200, \mathrm{MeOH})$.

Boc-D-phenylalanine-2-morpholinoanilide $(R-1 \mathrm{~b})$ A solution of Boc-D-phenylalanine (1000 mg, $3.7 \mathrm{mmol})$ and 2-morpholinoaniline $(611 \mathrm{mg}, 3.4 \mathrm{mmol})$ in ethyl acetate/ pyridine $(2: 1,15 \mathrm{~mL})$ was cooled to $-20{ }^{\circ} \mathrm{C}$ in an isopropanol-dry ice bath, and a solution of $\mathrm{T}^{3} \mathrm{P}^{\circledR}$ in ethyl acetate $(50 \%, 4.05 \mathrm{~mL}, 6.8 \mathrm{mmol})$ was added in several portions. The reaction mixture was stirred overnight at $0{ }^{\circ} \mathrm{C}$. Subsequently, ethyl acetate $(30 \mathrm{~mL})$ was added, and the mixture was washed with $0.5 \mathrm{~N}$ hydrochloric acid $(1 \times 30 \mathrm{~mL})$. The organic layer was dried over sodium sulfate, and the solvent was removed under reduced pressure. The crude product was purified by column chromatography eluting with ethyl acetate/heptane. Yield: $1398 \mathrm{mg}$ (3.22 mmol, 95\%; HPLC purity $\left.99.9 \%, t_{\mathrm{R}}=14.2 \mathrm{~min}\right)$, white solid, m.p. $155-156{ }^{\circ} \mathrm{C}$. ${ }^{1} \mathrm{H}$ NMR (400 MHz, DMSO-d6): $\delta=9.38$ (s, NH, 1H), 8.21 (d, Ar-H, $J=7.8 \mathrm{~Hz}, 1 \mathrm{H}), 7.47$ (d, Ar-H, $J=8.3 \mathrm{~Hz}, 1 \mathrm{H})$, 7.34-7.16 (m, Ar-H, 6H), 7.16-7.04 (m, ArH+NH, 2H), 
4.42-4.31 (m, $\left.\mathrm{CH}-\mathrm{CH}_{2}, 1 \mathrm{H}\right), 3.88-3.68$ (m, $\mathrm{CH}_{2}-\mathrm{O}-\mathrm{CH}_{2}$, $4 \mathrm{H}), 3.24$ (dd, $\left.\mathrm{CH}-\mathrm{CH}_{2}, J=13.8,4.5 \mathrm{~Hz}, 1 \mathrm{H}\right), 2.87-2.75$ $\left(\mathrm{m}, \mathrm{CH}_{2}-\mathrm{N}-\mathrm{CH}_{2}+\mathrm{CH}-\mathrm{CH}_{2}, 3 \mathrm{H}\right), 2.72-2.66\left(\mathrm{~m}, \mathrm{CH}_{2}-\right.$ $\left.\mathrm{N}-\mathrm{CH}_{2}, 2 \mathrm{H}\right), 1.30$ (s, $\left.\mathrm{C}\left(\mathrm{CH}_{3}\right)_{3}, 9 \mathrm{H}\right)$ ppm. HRMS $\left(\mathrm{ESI}^{+}\right)$: $\mathrm{m} / \mathrm{z}[\mathrm{M}+\mathrm{H}]^{+}$calcd for $\mathrm{C}_{24} \mathrm{H}_{32} \mathrm{~N}_{3} \mathrm{O}_{4}{ }^{+}, 426.2388$; found: 426.2381. Specific rotation, $[\alpha]_{\mathrm{D}}^{25}+21.7(c 0.307, \mathrm{MeOH})$.

\section{Na-2-thiophenoyl-D-phenylalanine-2-morpholinoanilide}

( $R$-2) Compound $R$-1b (250 mg, $0.59 \mathrm{mmol})$ was dissolved in dichloromethane/trifluoroacetic acid (1:1) and stirred for $1 \mathrm{~h}$ at room temperature. The solvent was removed under reduced pressure and the crude product was co-evaporated successively thrice with toluene and thrice with chloroform. The residue was dissolved in dichloromethane followed by the addition of diisopropylethylamine $(308 \mu \mathrm{L}, 1.77 \mathrm{mmol})$ and 2-thiophenecarboxylic acid $(75 \mathrm{mg}, 0.59 \mathrm{mmol})$. A solution of $\mathrm{PyBOP}^{\circledR}$ (338 mg, $0.65 \mathrm{mmol}$ ) was added under light protection and argon. After stirring overnight, the reaction mix was washed twice with $0.5 \mathrm{~N}$ hydrochloric acid. The organic layer was dried over sodium sulfate, and the solvent was removed under reduced pressure. The crude product was purified by flash chromatography eluting with ethyl acetate/heptane. Yield: $204 \mathrm{mg}$ (0.47 mmol, 80\%; HPLC purity $99.0 \%, t_{\mathrm{R}}=4.3 \mathrm{~min}, 99.9 \% \mathrm{ee}$ ) colourless, glass-like substance. ${ }^{1} \mathrm{H}$ NMR $\left(400 \mathrm{MHz}, \mathrm{CDCl}_{3}\right): \delta=8.80$ (s, NH, 1H), 8.40 (dd, Ar-H, J=8.1, $1.5 \mathrm{~Hz}, 1 \mathrm{H}), 7.52$ (dd, Ar-H, $J=3.8,1.1 \mathrm{~Hz}, 1 \mathrm{H}), 7.50(\mathrm{dd}$, Ar-H, $J=5.0,1.1 \mathrm{~Hz}, 1 \mathrm{H})$, 7.32-7.25 (m, Ar-H, 4H), 7.24-7.04 (m, Ar-H, 5H), 6.81 (d, $\mathrm{NH}, J=7.7 \mathrm{~Hz}, 1 \mathrm{H}), 4.94\left(\mathrm{~m}, \mathrm{CH}-\mathrm{CH}_{2}, 1 \mathrm{H}\right), 3.68-3.51(\mathrm{~m}$, $\mathrm{CH}_{2}-\mathrm{O}-\mathrm{CH}_{2}, 4 \mathrm{H}$ ), 3.39 (dd, CH-CH ${ }_{2}, J=13.6,5.4 \mathrm{~Hz}, 1 \mathrm{H}$ ), 3.23 (dd, CH-CH $\left.\mathbf{H}_{2}, J=13.6,8.0 \mathrm{~Hz}, 1 \mathrm{H}\right), 2.70-2.49$ (m, $\left.\mathrm{CH}_{2}-\mathrm{N}-\mathrm{CH}_{2}, 4 \mathrm{H}\right)$ ppm. APT ${ }^{13} \mathrm{C} \mathrm{NMR}\left(101 \mathrm{MHz}, \mathrm{CDCl}_{3}\right)$ : $\delta=168.8,161.6,141.3,138.1,136.6,133.0,130.9,129.5$, 129.0, 128.8, 128.0, 127.3, 126.0, 124.5, 120.9, 119.6, 67.4, 56.3, 52.6, $38.7 \mathrm{ppm}$. HRMS $\left(\mathrm{ESI}^{+}\right): \mathrm{m} / z[\mathrm{M}+\mathrm{H}]^{+}$calcd for $\mathrm{C}_{24} \mathrm{H}_{26} \mathrm{~N}_{3} \mathrm{O}_{3} \mathrm{~S}^{+}, 436.1690$; found: 436.1690 ; $[\mathrm{M}+\mathrm{Na}]^{+}$calcd for $\mathrm{C}_{24} \mathrm{H}_{25} \mathrm{~N}_{3} \mathrm{O}_{3} \mathrm{SNa}^{+}$, 458.1509; found: 458.1506. Specific rotation, $[\alpha]_{\mathrm{D}}^{25}+55.2(c 0.240, \mathrm{MeOH})$.

\section{X-ray crystallography}

A crystal of rac-2 suitable for single-crystal X-ray diffraction was obtained from a solution in methanol/water by slow evaporation of the solvents at ambient conditions. The X-ray intensity data were collected on a Stoe IPDS II diffractometer using graphite-monochromated Mo- $\mathrm{K}_{\alpha}$ radiation. The crystal structure was solved with SHELXT (Sheldrick 2015b) and refined with SHELXL-2018/3 (Sheldrick 2015a). Carbonbound hydrogen atoms were placed in geometrically calculated positions and refined with an appropriate riding model. Hydrogen atoms bonded to nitrogen were located via difference Fourier syntheses and refined freely. Structure pictures were drawn with Diamond (Brandenburg 2018) and Mercury (Macrae et al. 2020). The packing index was calculated with Platon (Spek 2009).

Crystal data for rac-2: $\mathrm{C}_{24} \mathrm{H}_{25} \mathrm{~N}_{3} \mathrm{O}_{3} \mathrm{~S}, M_{\mathrm{r}}=435.53$, $T=170(2) \mathrm{K}, \lambda=0.71073 \AA$, monoclinic, space group $P 2_{1} / n, a=9.6017(4), b=9.8739(3), c=23.2482(12)$ $\AA, \quad \beta=101.851(4)^{\circ}, \quad V=2157.09(16) \AA^{3}, \quad Z=4$, $\rho_{\text {calc }}=1.341 \mathrm{mg} \mathrm{m}^{-3}, \mu=0.182 \mathrm{~mm}^{-1}, F(000)=920$, crystal size $=0.165 \times 0.152 \times 0.131 \mathrm{~mm}, \theta$ range $=1.79-27.41^{\circ}$, reflections collected/unique $=13,647 / 4846\left(R_{\text {int }}=0.0557\right), 288$ parameters, $S=1.017, R 1[I>2 \sigma(I)]=0.0449, w R 2=0.1110$, $\Delta \rho_{\max }, \Delta \rho_{\min }=0.281,-0.322 \mathrm{e}^{-3}$.

\section{Microbiological assays}

MIC determination against $M$. smegmatis $\mathrm{mc}^{2} 155$ pTEC27 and M. abscessus ATCC 19977 pTEC27. MICs were determined by the broth microdilution method. 96-well flat bottom tissue culture plates (Sarstedt, 83.3924.500) were used (Richter et al. 2018). In the second well of each row, two times of the desired highest concentration of each compound was added in $7 \mathrm{H} 9$ medium supplemented with $10 \%$ ADS and $0.05 \%$ polysorbate 80. Each compound was diluted twofold in a ten-point serial dilution. The concentration of the starting inoculum was $5 \times 10^{5}$ cells $\mathrm{mL}^{-1}$. The starting inoculum was diluted from a pre-culture at the mid-log phase $\left(\mathrm{OD}_{600} 0.3\right.$ to 0.7$)$ and an $\mathrm{OD}_{600}$ of 0.1 was correlated to $1 \times 10^{8} \mathrm{CFU} \mathrm{mL} \mathrm{mL}^{-1}$. The plates were sealed with parafilm, placed in a container with moist tissue and incubated for four days at $37^{\circ} \mathrm{C}$. Each plate had eight negative controls ( $1 \%$ dimethylsulfoxide) and eight positive controls ( $100 \mu \mathrm{M}$ amikacin). After incubation, the plates were monitored by OD measurement at $590 \mathrm{~nm}$ (Tecan SpectraFluor). The assay was performed in duplicate and results were validated by RFP measurement. Data analysis: Every assay plate contained eight wells with dimethylsulfoxide (1\%) as negative control, which corresponds to $100 \%$ bacterial growth and eight wells with amikacin $(100 \mu \mathrm{M})$ as positive control in which $100 \%$ inhibition of bacterial growth was reached. Controls were used to monitor the assay quality through determination of the $Z^{\prime}$ score. The $Z^{\prime}$ factor was calculated as follows:

$Z^{\prime}=1-\frac{3\left(\mathrm{SD}_{\text {amikacin }}+\mathrm{SD}_{\mathrm{DMSO}}\right)}{M_{\text {amikacin }}-M_{\mathrm{DMSO}}}$

SD is the standard deviation, and $M$ is the mean.

The percentage of growth inhibition was calculated by the equation:

$\%$ Growth inhibition

$$
=-100 \% \times \frac{\mathrm{OD}_{590}(\text { sample })-\mathrm{OD}_{590}(\mathrm{DMSO})}{\mathrm{OD}_{590}(\mathrm{DMSO})-\mathrm{OD}_{590}(\text { amikacin })}
$$




\section{Cytotoxicity assay}

Human tumor cell lines A375 (melanoma), HT29 (colon adenocarcinoma), MCF-7 (breast adenocarcinoma), A2780 (ovarian carcinoma) and non-malignant mouse fibroblasts NIH 3 T3 were used. The cell lines were obtained from the Department of Oncology, Martin-Luther-Universität Halle-Wittenberg (Halle (Saale), Germany). Cultures were maintained as monolayers in RPMI 1640 medium with L-glutamine (Capricorn Scientific GmbH, Ebsdorfergrund, Germany) supplemented with $10 \%$ heat inactivated fetal bovine serum (Sigma-Aldrich Chemie $\mathrm{GmbH}$, Steinheim, Germany) and penicillin/streptomycin (Capricorn Scientific $\mathrm{GmbH}$, Ebsdorfergrund, Germany) at $37^{\circ} \mathrm{C}$ in a humidified atmosphere with 5\% carbon dioxide.

The cytotoxicity of the compounds was evaluated using the sulforhodamine B (SRB, Kiton-Red S, ABCR) microculture colorimetric assay. Cells were seeded into 96-well plates on day 0 . After $24 \mathrm{~h}$, the cells were treated with different concentrations of the compounds to be tested. The final concentration of dimethylsulfoxide/dimethylformamide never exceeded $0.5 \%$, which was non-toxic to the cells. After a 72-h treatment, the supernatant medium from the 96-well plates was discarded, the cells were fixed with $10 \%$ trichloroacetic acid and allowed to rest at $4{ }^{\circ} \mathrm{C}$. After $24 \mathrm{~h}$ fixation, the cells were washed in a strip washer and dyed with SRB solution $(100 \mu \mathrm{L}, 0.4 \%$, in $1 \%$ acetic acid) for about $20 \mathrm{~min}$. After dying, the plates were washed four times with $1 \%$ acetic acid to remove the excess of the dye and allowed to air-dry overnight. TRIS base solution $(200 \mu \mathrm{L}$, $10 \mathrm{mM}$ ) was added to each well and the absorbance was measured at $\lambda=570 \mathrm{~nm}$ using a 96-well plate reader (Tecan Spectra, Crailsheim, Germany). The $\mathrm{EC}_{50}$ values were averaged from three independent experiments performed each in triplicate calculated from semi-logarithmic dose-response curves applying a non-linear 4P Hills-slope equation (GraphPad Prism5; variables top and bottom were set to 100 and 0 , respectively).

\section{Results and discussion}

\section{Synthesis}

For the synthesis of the target compound 2, two different synthetic routes were investigated (Scheme 1). Method A started with the unprotected amino acid L-phenylalanine, which was reacted with 2-thiophenecarbonyl chloride
A
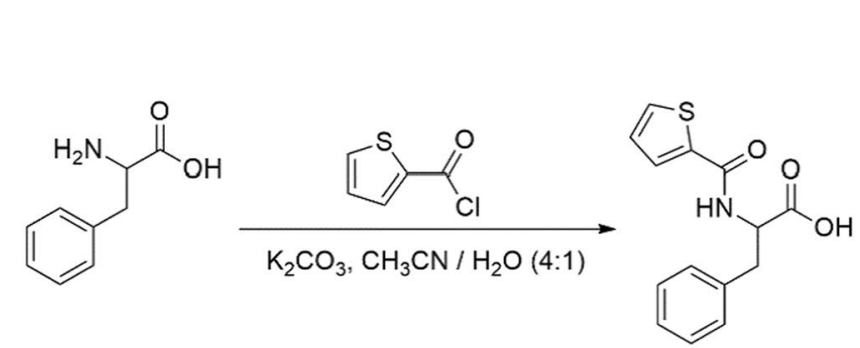

$1 \mathrm{a}$

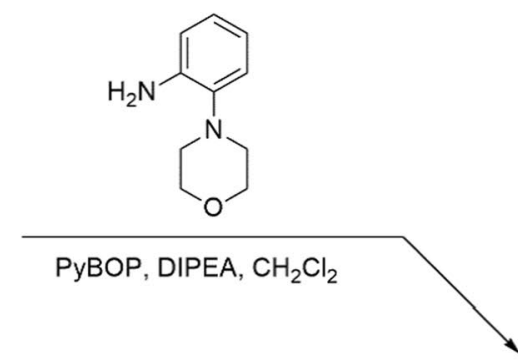<smiles>O=C(NC(Cc1ccccc1)C(=O)Nc1ccccc1N1CCOCC1)c1cccs1</smiles><smiles>CC(C)(C)OC(=O)NC(Cc1ccccc1)C(=O)Nc1ccccc1N1CCOCC1</smiles>

1. TFA $/ \mathrm{CH}_{2} \mathrm{Cl}_{2}(1: 1)$

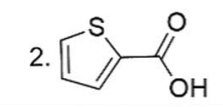

PyBOP, DIPEA, $\mathrm{CH}_{2} \mathrm{Cl}_{2}$

1b

Scheme 1 Synthesis of 2. Method A: $N$-acylation of D- or L-phenylalanine with 2-thiophenecarbonyl chloride followed by amide coupling with 2-morpholinoanilin. Method B: Amide coupling of D- or L-Bocphenylalanine with 2-morpholinoaniline followed by Boc deprotec- tion and amide coupling with 2-thiophenecarboxylic acid. PyBOP ${ }^{\circledR}$ (benzotriazolyloxy-tris[pyrrolidino]-phosphonium hexafluorophosphate), DIPEA (diisopropylethylamine), T3P ${ }^{\circledR}$ (propanephosphonic acid anhydride), TFA (trifluoroacetic acid) 
to afford the amide coupling product $N \alpha$-2-thiophenoylphenylalanine (1a) in accordance with the literature (Draper et al. 2015; Skogh et al. 2017). In the second step, 1a was coupled with 2-morpholinoaniline using $\mathrm{PyBOP}^{\circledR}$ as coupling reagent (Coste et al. 1990) in the presence of diisopropylethylamine (Hünig's base) to give the targeted $\mathbf{2}$ in good yield. X-ray crystallography first revealed the formation of a racemic product, which was confirmed for the bulk sample by the absence of specific rotation and chiral HPLC (Fig. 1). The compound also showed no chiroptical signal in the CD spectrum. The racemisation occurs during the conversion of 1a to rac-2 using PyBOP ${ }^{\circledR}$ (Coste et al. 1990), as the intermediate 1a still has an $e e$ of $99.1 \%$ which was detected by chiral HPLC (Figure S10). The presence of a specific rotation signal also indicates that 1a is not racemic. During the conversion to rac-2, the carboxy group is activated as a hydroxybenzotriazol ester, which increases the electron withdrawing effect on the chiral centre at the $\alpha$-carbon atom of the amino acid and accounts for the observed racemisation in the presence of diisopropylethylamine. As expected, applying method A for D-phenylalanine as starting material likewise afforded $r a c-\mathbf{2}$. The crystal structure of $r a c-\mathbf{2}$ is described in "Structural description of $\mathrm{rac}-2$ ".

In method B, starting with Boc-protected D- or L-phenylalanine, amide bond-formations were achieved with the aid of the coupling reagents T3P ${ }^{\circledR}$ (Wissmann and Kleiner 1980) and $\mathrm{PyBOP}^{\circledR}$, which are known from peptide synthesis for a low degree of racemization or epimerization (Dunetz et al. 2011; Pelay-Gimeno et al. 2013; Waghmare et al. 2014). Coupling with 2-morpholinoaniline was carried out using $\mathrm{T}^{\mathrm{P}} \mathrm{P}^{\circledR}$ in ethyl acetate/pyridine $(2: 1)$ at $0{ }^{\circ} \mathrm{C}$ for conservation of the configuration at the asymmetric $\alpha$-carbon atom of the amino acid. After isolation of $\mathbf{1 b}$, the Boc-protecting group was removed with trifluoroacetic acid to obtain D- or L-phenylalanine-2-morpholinoanilide, which was reacted in situ with 2-thiophenecarboxylic acid, using $\mathrm{PyBOP}^{\circledR}$ and diisopropylethylamine. Specific rotation measurements and CD spectroscopy proved the formation of optically active products. Both enantiomers, viz. $R-\mathbf{2}$ obtained from D-phenylalanine and $S-2$ derived from L-phenylalanine, show equal but opposite $\mathrm{CD}$ signals in their electronic absorption range of 200-300 nm, as expected (Fig. 2). Chiral HPLC revealed 99.9\% ee for both $R$ - and $S-2$ (Fig. 1).

Despite intense efforts using different solvent systems for crystallization, single-crystals of $R-\mathbf{2}$ and $S-2$ suitable for $\mathrm{X}$-ray diffraction could not be obtained. All attempts resulted in the formation of glassy materials. For $R-\mathbf{2}$ isolated from chloroform, the amorphous nature of the solid was confirmed by a DSC scan, which revealed a glass transition at $45-52{ }^{\circ} \mathrm{C}$ (see Supplementary Material). Packing difficulties due to an awkward molecular shape can be put forward to explain inability of $R$ - and $S-2$ to form crystalline solids.
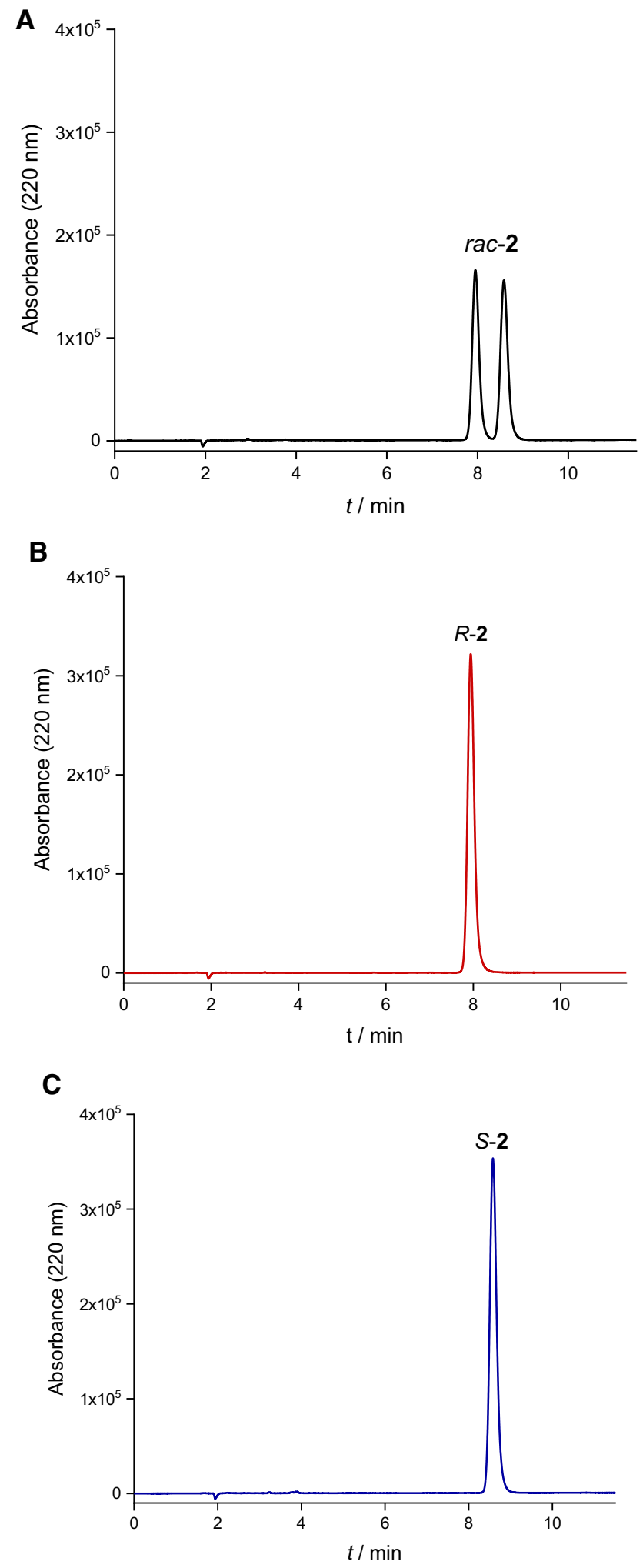

Fig. 1 Chiral HPLC chromatograms of rac-2 (A), R-2 (B) and $S$-2 (C) (Chiralpak IB-N3, acetonitrile/water 55:45) 

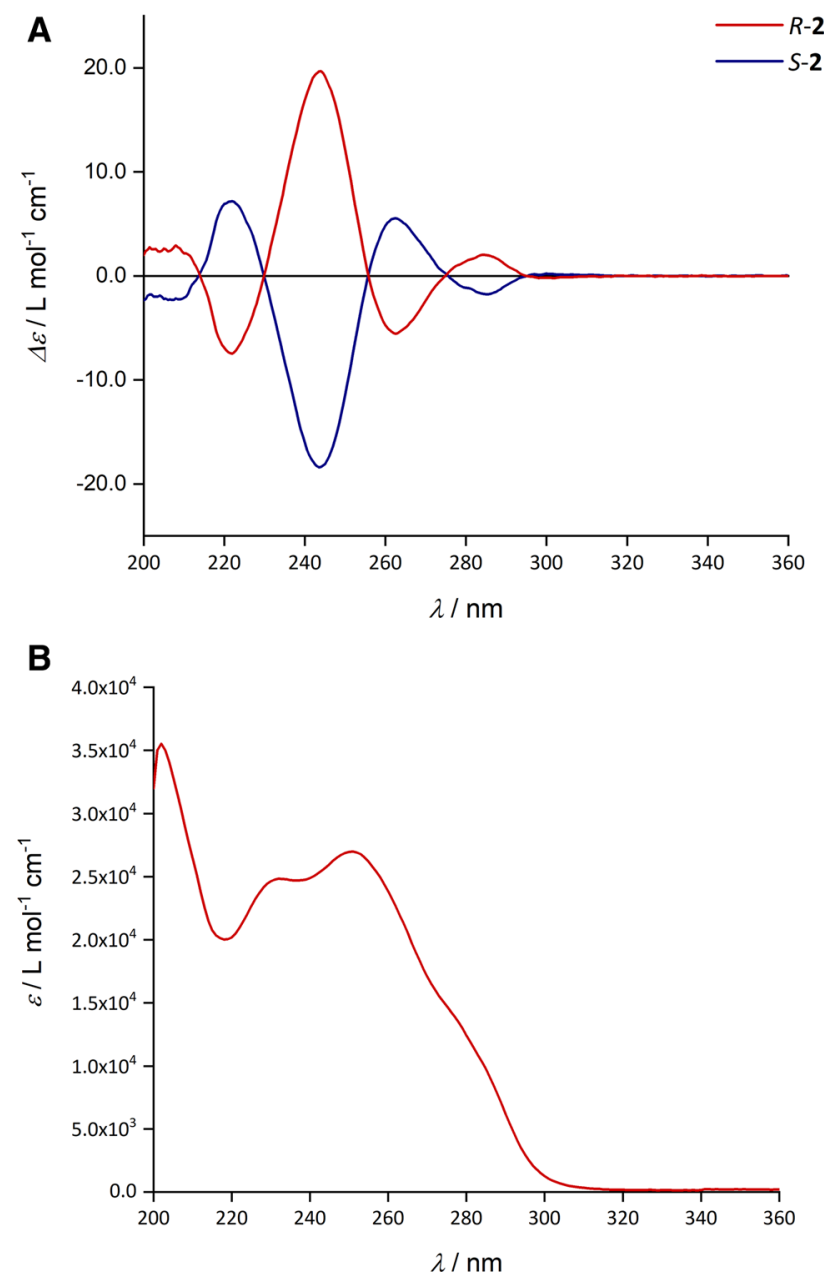

Fig. 2 A CD spectra of $R$-2 $\left(c=5.51 \times 10^{-4} \mathrm{~mol} \mathrm{~L}^{-1}\right)$ and $S$ $2\left(c=4.59 \times 10^{-4} \mathrm{~mol} \mathrm{~L}^{-1}\right)$ in methanol. B UV spectrum of $R-2$ in methanol $\left(c=9.18 \times 10^{-6} \mathrm{~mol} \mathrm{~L}^{-1}\right)$. UV spectra of $S-2$ and $\mathrm{rac}-\mathbf{2}$ in methanol can be found in the Supplementary Material

Clearly, the formation of centrosymmetric hydrogen-bonded dimers, as encountered in the crystal structure of the racemic counterpart ( $r a c-2$, see "Structural description of $r a c-2 ")$ is impossible for enantiopure $\mathbf{2}$.

\section{Structural description of rac-2}

Solvent-free $r a c-2$ was found to crystallize in the centrosymmetric monoclinic space group $P 2_{1} / n$ with four molecules in the unit cell. Figure 3 shows the molecular structure of the $S$-enantiomer (corresponding to the L form) in the chosen asymmetric unit of rac-2. As mentioned above, the molecule exhibits a somewhat awkward irregular shape. Both amide groups adopt a $Z$ conformation. The twist angle $\tau$ is $173.7^{\circ}$ for the 2-morpholinoanilide group and $-170.3^{\circ}$ for the $N \alpha$-2-thiophenoyl amide group, indicating some out-ofplane deformation of the amide linkages (Winkler and Dunitz 1971; Yamada 2000). The pyramidality at the amide $\mathrm{N}$

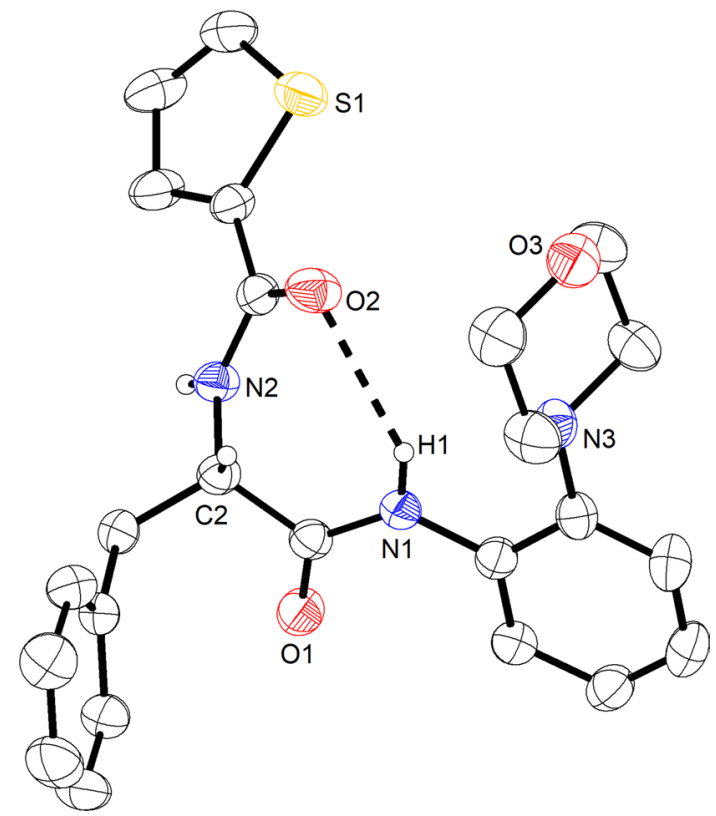

Fig. 3 Molecular structure of the $S$-enantiomer in the chosen asymmetric unit of the centrosymmetric crystal structure of rac-2. Displacement ellipsoids are drawn at the $50 \%$ probability level, and hydrogen atoms are represented by small spheres of arbitrary radius. Those attached to carbon are omitted for clarity, except for the asymmetric carbon atom $\mathrm{C} 2$. The dashed line represents a hydrogen bond: $\mathrm{N} 1-\mathrm{H} 1=0.88(2), \quad \mathrm{H} 1 \cdots \mathrm{O} 2=2.45(2), \quad \mathrm{N} 1 \cdots \mathrm{O} 2=3.158(2) \AA$ $\mathrm{H} 1 \cdots \mathrm{O} 2=138(2)^{\circ}$

atoms $\chi_{\mathrm{N}}$ (Yamada 2000), according to Winkler and Dunitz (1971), is small at $-1.9^{\circ}$ and $-2.5^{\circ}$ for $\mathrm{N} 1$ and $\mathrm{N} 2$, respectively, and $\chi_{\mathrm{C}}$ is close to zero in both amide groups. N1 of the 2-morpholinoanilide group forms an intramolecular hydrogen bond to $\mathrm{O} 2$ of the thiophenoyl group with a S(7) motif (Bernstein et al. 1995). The mean plane calculated through the morpholine saturated six-membered ring is inclined to the mean plane of the aniline aromatic ring by ca. $72^{\circ}$. The morpholine ring adopts a low-energy chair conformation, and the coordination at the morpholine nitrogen atom N3 is markedly pyramidal. Structurally characterized examples of 2-morpholinoanilides are surprisingly rare. A search of the Cambridge Structural Database [CSD; version 5.41 with August 2020 updates (Groom et al. 2016)] revealed only two structures, viz. the 2-morpholinoanilides of picolinic acid (CSD refcode: HOBQEW) and pyrimidine-4-carboxylic acid (HOBQAS) (Li et al. 2014), in which the 2-morpholinoanilide moiety shows a similar structure as in $\mathbf{r a c}-\mathbf{2}$.

In the crystal, the molecules form a centrosymmetric dimer about a crystallographic center of symmetry with a $\mathrm{R}_{2}^{2}(10)$ hydrogen bond motif, involving $\mathrm{N} 2$ as hydrogen bond donor and $\mathrm{O} 2$ as acceptor (Fig. 4). The hydrogen bonding parameters for $r a c-2$ are within expected ranges (Thakuria et al. 2017), and the observed hydrogen bonding scheme is in line with Etter's third rule for hydrogen bonding, which 


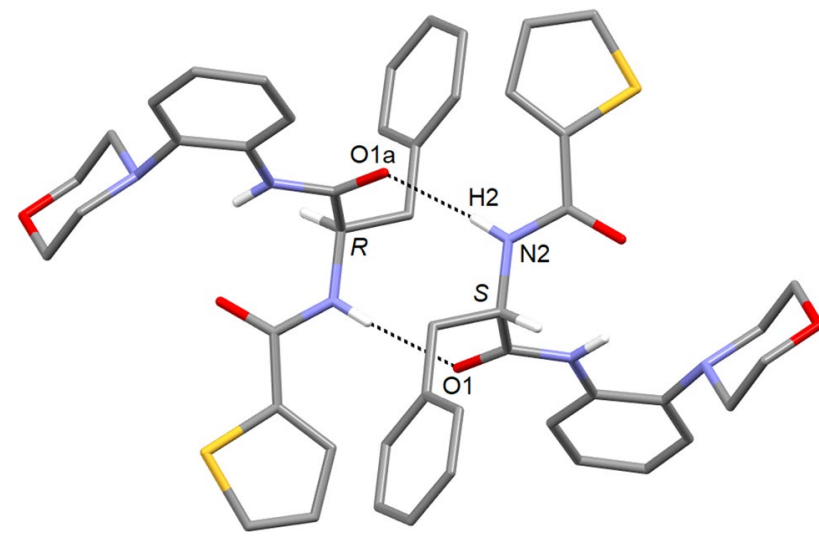

Fig. 4 Centrosymmetric dimer in the crystal structure of rac2 with a $\mathrm{R}_{2}^{2}(10)$ hydrogen bond motif. Carbon-bound hydrogen atoms are omitted for clarity, except for the asymmetric carbon atom. The dashed line represents hydrogen bonds: $\mathrm{N}-\mathrm{H} 1=0.82(2)$, $\mathrm{H} 1 \cdots \mathrm{O} 2=2.11(3), \quad \mathrm{N} 1 \cdots \mathrm{O} 2=2.925(2) \AA, \quad \mathrm{N} 1-\mathrm{H} 1 \cdots \mathrm{O} 2=174(2)^{\circ}$. Symmetry code: (a) $-x+1,-y+1,-z+1$

states that the best hydrogen bond donors and acceptors remaining after intramolecular hydrogen bond formation form intermolecular hydrogen bonds to one another (Etter 1990). The calculated packing index of $69.1 \%$ is typical of molecular crystals (Kitajgorodskij 1973).

\section{Biological evaluation of rac-2, $R-2$ and $S-2$}

Anti-mycobacterial activities of racemic and enantiopure 2 were determined against two species of fast-growing mycobacteria, viz. M. abscessus ATCC 19977 and M. smegmatis mc2 155, in a microplate dilution assay (Richter et al. 2018). The results are shown in Figure S9 in the Supplementary Material. Against M. abscessus, a pathogenic and rifampicin-resistant bacterium, $R-\mathbf{2}$ possesses an $\mathrm{MIC}_{90}$ of $6.25 \mu \mathrm{M}$, which is consistent with the literature (Low et al. 2017; Richter et al. 2018). In contrast, $S$-2 does not show activity against these two mycobacterial species, and rac-2 causes growth inhibition up to a concentration of $25 \mu \mathrm{M}$. Against M. smegmatis, which is generally considered nonpathogenic (Joseph Antony Sundarsingh et al. 2020), lower MICs than those against $M$. abscessus were observed for $R-2$ and $r a c-2$ (Table 1). Likewise, $S-2$ shows no inhibitory effect on the growth of this mycobacterial species.

The lower sensitivity of M. abscessus compared with $M$. smegmatis to antibiotic agents is described in the literature (Maurer et al. 2014). Various causes, such as lower cell wall permeability, enzymatic inactivation or structural differences in the target, can be responsible for this. An exact elucidation of the mechanism would have exceeded the scope of the investigation described here.

Cytotoxicity of $R-\mathbf{2}, S-2$ and rac-2 against eukaryotic cells was investigated by means of a RSB assay, analyzing the
Table 1 In vitro antimycobacterial activity and cytotoxicity of $R-2, S$ 2 and $\mathrm{rac}-2$

\begin{tabular}{llll}
\hline & $\begin{array}{l}\mathrm{MIC}_{90} / \mu \mathrm{M} \\
\begin{array}{l}\text { M. abscessus ATCC } \\
19977\end{array}\end{array}$ & $\begin{array}{l}\mathrm{MIC}_{90} / \mu \mathrm{M} \\
\text { M. smegmatis } \mathrm{mc2} 2 \\
155\end{array}$ & $\mathrm{EC}_{50} / \mu \mathrm{M}^{\mathrm{a}}$ \\
\hline$R-2$ & 6.25 & 0.78 & $>30$ \\
$S-2$ & $>100$ & $>100$ & $>30$ \\
rac-2 & 25 & 1.56 & $>30$ \\
\hline
\end{tabular}

${ }^{a}$ RSB assay against the cell lines A375, HT29, MCF-7, A2780 and NIH 3 T3

effect of the compounds on a panel of mammalian cell lines. The cytotoxicity assay showed that neither of the enantiomers and the racemate of $\mathbf{2}$ had a cytotoxic effect up to a concentration of $30 \mu \mathrm{M}$ against the cell lines A375 (melanoma), HT29 (colon cancer), MCF-7 (breast cancer) (Soule et al. 1973), A2780 (ovarian cancer) and NIH 3T3 (mouse fibroblast) used in the assay (Table 1).

\section{Conclusion}

The title compound (2) is a promising lead candidate for a synthetic RNA polymerase inhibitor against various mycobacterial species. Racemization-free synthesis of both enantiomers from Boc-protected D- or L-phenylalanine was achieved by exploiting the $\mathrm{T} \mathrm{P}^{\circledR}$ and $\mathrm{PyBOP}^{\circledR}$ reagents for amide coupling reactions, as confirmed by $\mathrm{CD}$ spectroscopy and chiral HPLC. This synthetic route avoids the need for subsequent separation of the enantiomers. X-ray crystallography of $\mathrm{rac}-\mathbf{2}$ revealed a crystal and molecular structure of a compound of this class for the first time, as far as we are able to ascertain. Structural knowledge should be useful for further exploration of $\mathbf{2}$ and derivatives in medicinal chemistry. We observed different activities for both enantiomers of $\mathbf{2}$ against $M$. smegmatis and against the pathogenic M. abscessus, underlining the importance of absolute configuration for activity. Only the $R$ enantiomer $(R-2)$, derived from the non-proteinogenic amino acid D-phenylalanine shows antimycobacterial activity. No cytotoxicity against five mammalian cell lines was observed. The results of the present work encourage optimization of antimycobacterial activities (i.e. $\mathrm{MIC}<1 \mu \mathrm{M})$ and pharmacokinetic properties of $N \alpha$-aroyl$\mathrm{N}$-aryl-phenylalanine amides.

Supplementary material NMR and UV spectra for $\mathbf{2}$, DSC analysis of $R-2$ and in vitro growth inhibition activity of R-2, S-2 and rac-2 against M. abscessus ATCC 19977 and M. smegmatis mc2 155. CCDC 2049487 contains the supplementary crystallographic data for this paper. These data can be obtained free of charge from the Cambridge 
Crystallographic Data Centre via http://www.ccdc.cam.ac. uk/structures.

Supplementary Information The online version contains supplementary material available at https://doi.org/10.1007/s00726-021-03044-1.

Acknowledgements We would like to thank Dr. Christian Ihling and Antje Herbrich-Peters for measuring the HRMS spectra, and Eric Lehner and Kerstin Schwarz for the DSC analysis. We are grateful to Dr. Andrea Porzel and Gudrun Hahn for UV and CD spectroscopy and specific rotation measurements. Professor Kurt Merzweiler is gratefully acknowledged for providing diffractometer time and Dr. Christoph Wagner for his help with the X-ray intensity data collection. Thanks are due to Dr. Dieter Ströhl for the NMR spectroscopy, Dr. Thomas Müller for providing the cell lines, and Dr. Nadine Taudte and Dr. Jens-Ulrich Rahfeld for providing and maintaining the biosafety 2 facility. R.W.S. would like to thank Dr. Richard Goddard for helpful discussions.

Funding Open Access funding enabled and organized by Projekt DEAL. This work was funded by the Deutsche Forschungsgemeinschaft (DFG, German Research Foundation)-432291016.

Data availability Supplementary crystallographic data including reflection files have been deposited with the Cambridge Crystallographic Data Centre.

Code availability Not applicable.

\section{Declarations}

Conflict of interest There are no conflicts of interest/competing interests to declare.

Ethics approval Not applicable.

Consent to participate Not applicable.

Consent for publication All authors have seen the manuscript and agree to its publication.

Open Access This article is licensed under a Creative Commons Attribution 4.0 International License, which permits use, sharing, adaptation, distribution and reproduction in any medium or format, as long as you give appropriate credit to the original author(s) and the source, provide a link to the Creative Commons licence, and indicate if changes were made. The images or other third party material in this article are included in the article's Creative Commons licence, unless indicated otherwise in a credit line to the material. If material is not included in the article's Creative Commons licence and your intended use is not permitted by statutory regulation or exceeds the permitted use, you will need to obtain permission directly from the copyright holder. To view a copy of this licence, visit http://creativecommons.org/licenses/by/4.0/.

\section{References}

Ahmed I, Tiberi S, Farooqi J, Jabeen K, Yeboah-Manu D, Migliori GB, Hasan R (2020) Non-tuberculous mycobacterial infectionsa neglected and emerging problem. Int J Infect Dis 92:S46-S50. https://doi.org/10.1016/j.ijid.2020.02.022
Ballell L, Bates RH, Young RJ, Alvarez-Gomez D, Alvarez-Ruiz E, Barroso V, Blanco D, Crespo B, Escribano J, Gonzalez R, Lozano S, Huss S, Santos-Villarejo A, Martin-Plaza JJ, Mendoza A, Rebollo-Lopez MJ, Remuinan-Blanco M, Lavandera JL, PerezHerran E, Gamo-Benito FJ, Garcia-Bustos JF, Barros D, Castro JP, Cammack N (2013) Fueling open-source drug discovery: 177 small-molecule leads against tuberculosis. ChemMedChem 8(2):313-321. https://doi.org/10.1002/cmdc.201200428

Bernstein J, Davis RE, Shimoni L, Chang NL (1995) Patterns in hydrogen bonding-functionality and graph set analysis in crystals. Angew Chem Int Ed 34(15):1555-1573. https://doi.org/10.1002/ anie. 199515551

Brandenburg K (2018) Diamond, 3.2k3 edn. Crystal Impact GbR, Bonn

Bryant JM, Grogono DM, Rodriguez-Rincon D, Everall I, Brown KP, Moreno P, Verma D, Hill E, Drijkoningen J, Gilligan P, Esther CR, Noone PG, Giddings O, Bell SC, Thomson R, Wainwright CE, Coulter C, Pandey S, Wood ME, Stockwell RE, Ramsay KA, Sherrard LJ, Kidd TJ, Jabbour N, Johnson GR, Knibbs LD, Morawska L, Sly PD, Jones A, Bilton D, Laurenson I, Ruddy M, Bourke S, Bowler IC, Chapman SJ, Clayton A, Cullen M, Daniels T, Dempsey O, Denton M, Desai M, Drew RJ, Edenborough F, Evans J, Folb J, Humphrey H, Isalska B, Jensen-Fangel S, Jönsson B, Jones AM, Katzenstein TL, Lillebaek T, MacGregor G, Mayell S, Millar M, Modha D, Nash EF, O'Brien C, O'Brien D, Ohri C, Pao CS, Peckham D, Perrin F, Perry A, Pressler T, Prtak L, Qvist T, Robb A, Rodgers H, Schaffer K, Shafi N, van Ingen J, Walshaw M, Watson D, West N, Whitehouse J, Haworth CS, Harris SR, Ordway D, Parkhill J, Floto RA (2016) Emergence and spread of a human-transmissible multidrug-resistant nontuberculous mycobacterium. Science 354(6313):751-757

Coste J, Le-Nguyen D, Castro B (1990) PyBOP ${ }^{\circledR}$ : a new peptide coupling reagent devoid of toxic by-product. Tetrahedron Lett 31(2):205-208. https://doi.org/10.1016/S0040-4039(00)94371-5

Dartois V, Sizemore C, Dick T (2019) Editorial: NTM — the new uberbugs. Front Microbiol. https://doi.org/10.3389/fmicb.2019.01299

Draper ER, Mcdonald TO, Adams DJ (2015) A low molecular weight hydrogel with unusual gel aging. Chem Commun 51(30):65956597. https://doi.org/10.1039/c5cc01334h

Dunetz JR, Xiang Y, Baldwin A, Ringling J (2011) General and scalable amide bond formation with epimerization-prone substrates using T3P and pyridine. Org Lett 13(19):5048-5051. https://doi. org/10.1021/ol201875q

Ebright RH, Ebright YW, Mandal S, Wilde R, Li S (2015) Preparation of $N$-alpha-aroyl- $N$-aryl-phenylalaninamides as inhibitors of bacterial RNA polymerase and as antibacterials. WO2015120320A1

Etter MC (1990) Encoding and decoding hydrogen-bond patterns of organic-compounds. Acc Chem Res 23(4):120-126. https://doi. org/10.1021/ar00172a005

Ganapathy US, Dartois V, Dick T (2019) Repositioning rifamycins for Mycobacterium abscessus lung disease. Expert Opin Drug Discov 14(9):867-878. https://doi.org/10.1080/17460441.2019.1629414

Grobbelaar M, Louw GE, Sampson SL, van Helden PD, Donald PR, Warren RM (2019) Evolution of rifampicin treatment for tuberculosis. Infect Genet Evol 74:103937. https://doi.org/10.1016/j. meegid.2019.103937

Groom CR, Bruno IJ, Lightfoot MP, Ward SC (2016) The Cambridge Structural Database. Acta Crystallogr B Struct Sci Cryst Eng Mater 72(Pt 2):171-179. https://doi.org/10.1107/S205252061 6003954

Jeong J, Kim G, Moon C, Kim HJ, Kim TH, Jang J (2018) Pathogen Box screening for hit identification against Mycobacterium abscessus. PLoS One 13(4):e0195595. https://doi.org/10.1371/ journal.pone.0195595

Joseph Antony Sundarsingh T, Ranjitha J, Rajan A, Shankar V (2020) Features of the biochemistry of Mycobacterium smegmatis, as a possible model for Mycobacterium tuberculosis. J Infect Public 
Health 13(9):1255-1264. https://doi.org/10.1016/j.jiph.2020.06. 023

Kitajgorodskij AI (1973) Molecular crystals and molecules. Academic Press, New York

Lee M-R, Sheng W-H, Hung C-C, Yu C-J, Lee L-N, Hsueh P-R (2015) Mycobacterium abscessus complex infections in humans. Emerg Infect Dis 21(9):1638-1646. https://doi.org/10.3201/2109.141634

Li Q, Zhang S-Y, He G, Ai Z, Nack WA, Chen G (2014) Coppercatalyzed carboxamide-directed ortho amination of anilines with alkylamines at room temperature. Org Lett 16(6):1764-1767. https://doi.org/10.1021/o1500464x

Lin W, Mandal S, Degen D, Liu Y, Ebright YW, Li S, Feng Y, Zhang Y, Mandal S, Jiang Y, Liu S, Gigliotti M, Talaue M, Connell N, Das K, Arnold E, Ebright RH (2017) Structural basis of Mycobacterium tuberculosis transcription and transcription inhibition. Mol Cell 66(2):169-179.e168. https://doi.org/10.1016/j.molcel. 2017.03.001

Lopeman RC, Harrison J, Desai M, Cox JAG (2019) Mycobacterium abscessus: environmental bacterium turned clinical nightmare. Microorganisms. https://doi.org/10.3390/microorganisms7030090

Low JL, Wu M-L, Aziz DB, Laleu B, Dick T (2017) Screening of TB actives for activity against nontuberculous mycobacteria delivers high hit rates. Front Microbiol. https://doi.org/10.3389/fmicb. 2017.01539

Macrae CF, Sovago I, Cottrell SJ, Galek PTA, McCabe P, Pidcock E, Platings M, Shields GP, Stevens JS, Towler M, Wood PA (2020) Mercury 4.0: from visualization to analysis, design and prediction. J Appl Crystallogr 53(Pt 1):226-235. https://doi.org/10. 1107/S1600576719014092

Maurer FP, Bruderer VL, Ritter C, Castelberg C, Bloemberg GV, Böttger EC (2014) Lack of antimicrobial bactericidal activity in Mycobacterium abscessus. Antimicrob Agents Chemother 58(7):3828-3836. https://doi.org/10.1128/aac.02448-14

Nessar R, Cambau E, Reyrat JM, Murray A, Gicquel B (2012) Mycobacterium abscessus: a new antibiotic nightmare. J Antimicrob Chemother 67(4):810-818. https://doi.org/10.1093/jac/dkr578

Park IK, Olivier KN (2015) Nontuberculous mycobacteria in cystic fibrosis and non-cystic fibrosis bronchiectasis. Semin Respir Crit Care Med 36(02):217-224. https://doi.org/10.1055/s-0035-15467 51

Pelay-Gimeno M, García-Ramos Y, Jesús Martin M, Spengler J, Molina-Guijarro JM, Munt S, Francesch AM, Cuevas C, TullaPuche J, Albericio F (2013) The first total synthesis of the cyclodepsipeptide pipecolidepsin A. Nat Commun 4(1):2352. https://doi.org/10.1038/ncomms3352

Prideaux B, Via LE, Zimmerman MD, Eum S, Sarathy J, O'Brien P, Chen C, Kaya F, Weiner DM, Chen P-Y, Song T, Lee M, Shim TS, Cho JS, Kim W, Cho SN, Olivier KN, Barry CE, Dartois V (2015) The association between sterilizing activity and drug distribution into tuberculosis lesions. Nat Med 21(10):1223-1227. https://doi. org/10.1038/nm.3937

Richter A, Strauch A, Chao J, Ko M, Av-Gay Y (2018) Screening of preselected libraries targeting Mycobacterium abscessus for drug discovery. Antimicrob Agents Chemother 62(9):e00828-00181. https://doi.org/10.1128/AAC.00828-18

Shah I, Poojari V, Meshram H (2020) Multi-drug resistant and extensively-drug resistant tuberculosis. Indian J Pediatr 87(10):833839. https://doi.org/10.1007/s12098-020-03230-1

Sheldrick GM (2015a) Crystal structure refinement with SHELXL. Acta Crystallogr C Struct Chem 71(Pt 1):3-8. https://doi.org/10. $1107 /$ S2053229614024218
Sheldrick GM (2015b) SHELXT_-integrated space-group and crystal-structure determination. Acta Crystallogr A Found Adv 71(Pt 1):3-8. https://doi.org/10.1107/S2053273314026370

Skogh A, Friis SD, Skrydstrup T, Sandström A (2017) Palladiumcatalyzed aminocarbonylation in solid-phase peptide synthesis: a method for capping, cyclization, and isotope labeling. Org Lett 19(11):2873-2876. https://doi.org/10.1021/acs.orglett.7b01068

Soule HD, Vazquez J, Long A, Albert S, Brennan M (1973) A human cell line from a pleural effusion derived from a breast carcinoma. J Natl Cancer Inst 51(5):1409-1416. https://doi.org/10.1093/jnci/ 51.5.1409

Spek AL (2009) Structure validation in chemical crystallography. Acta Crystallogr D Biol Crystallogr 65(Pt 2):148-155. https://doi.org/ 10.1107/S090744490804362X

Stoffels K, Allix-Béguec C, Groenen G, Wanlin M, Berkvens D, Mathys V, Supply P, Fauville-Dufaux M (2013) From multidrugto extensively drug-resistant tuberculosis: upward trends as seen from a 15-year nationwide study. PLoS One 8(5):e63128. https:// doi.org/10.1371/journal.pone.0063128

Thakuria R, Sarma B, Nangia A (2017) 7.03-Hydrogen bonding in molecular crystals. In: Atwood JL (ed) Comprehensive supramolecular chemistry II. Elsevier, Oxford, pp 25-48. https://doi.org/ 10.1016/B978-0-12-409547-2.12598-3

To K, Cao R, Yegiazaryan A, Owens J, Venketaraman V (2020) General overview of nontuberculous Mycobacteria opportunistic pathogens: Mycobacterium avium and Mycobacterium abscessus. J Clin Med. https://doi.org/10.3390/jcm9082541

Waghmare AA, Hindupur RM, Pati HN (2014) Propylphosphonic anhydride $\left(\mathrm{T} 3 \mathrm{P}^{\circledR}\right)$ : an expedient reagent for organic synthesis. Rev J Chem 4(2):53-131. https://doi.org/10.1134/S207997801 4020034

Wassilew N, Hoffmann H, Andrejak C, Lange C (2016) Pulmonary disease caused by non-tuberculous Mycobacteria. Respiration 91(5):386-402. https://doi.org/10.1159/000445906

Weiss CH, Glassroth J (2012) Pulmonary disease caused by nontuberculous mycobacteria. Expert Rev Respir Med 6(6):597-613. https://doi.org/10.1586/ers.12.58

Winkler FK, Dunitz JD (1971) The non-planar amide group. J Mol Biol 59(1):169. https://doi.org/10.1016/0022-2836(71)90419-0

Wissmann H, Kleiner HJ (1980) New peptide-synthesis. Angew Chem Int Ed Engl 19(2):133-134. https://doi.org/10.1002/anie.19800 1331

Wu M-L, Aziz DB, Dartois V, Dick T (2018) NTM drug discovery: status, gaps and the way forward. Drug Discov Today 23(8):15021519. https://doi.org/10.1016/j.drudis.2018.04.001

Yamada S (2000) Sterically hindered twisted amides. In: Greenberg A, Breneann CM, Liebmann JF (eds) The amide linkage: structural significance in chemistry, biochemistry, and materials science. Wiley, New York, pp 215-246

Zumla AI, Gillespie SH, Hoelscher M, Philips PPJ, Cole ST, Abubakar I, McHugh TD, Schito M, Maeurer M, Nunn AJ (2014) New antituberculosis drugs, regimens, and adjunct therapies: needs, advances, and future prospects. Lancet Infect Dis 14(4):327-340. https://doi.org/10.1016/S1473-3099(13)70328-1

Publisher's Note Springer Nature remains neutral with regard to jurisdictional claims in published maps and institutional affiliations. 